\title{
Proteomic signature of fenugreek treated by methyl jasmonate and cholesterol
}

\author{
Joanna Ciura $^{1} \cdot$ Aleksandra Bocian $^{1}\left(\mathbb{D} \cdot\right.$ Anna Kononiuk $^{1} \cdot$ Magdalena Szeliga $^{1} \cdot$ \\ Marcin Jaromin ${ }^{1} \cdot$ Mirosław Tyrka ${ }^{1}$
}

Received: 6 June 2016/Revised: 23 March 2017/Accepted: 9 April 2017/Published online: 17 April 2017

(C) The Author(s) 2017. This article is an open access publication

\begin{abstract}
Main conclusion Changes in proteome level as a result of methyl jasmonate and cholesterol treatment were investigated. The identified proteins were often involved in response to stress caused by various treatments. Furthermore, 18 proteins were expressed in treatmentspecific manner.

In this study, the fenugreek plants were treated with methyl jasmonate (as an elicitor) and cholesterol (as a precursor of steroids and steroidal saponins) to check reaction at the level of the proteome to stress and to investigate steroidal saponin (diosgenin) biosynthesis. Proteins were separated by two-dimensional electrophoresis (2-DE) and identified by MALDI-ToF/ToF followed by database searches using Mascot search engine. Totally, 63 and 41 protein spots were differentially expressed after methyl jasmonate and cholesterol treatment, respectively. These proteins were classified into seven groups: photosynthesis, energy, metabolism, protein metabolism, secondary metabolism, stress and defense, and other. We found that 9 proteins were responsive to all treatments, and 18 proteins expressed in treatment-specific manner. Higher level of photosynthetic proteins sensitive to both biotic and abiotic stimuli was detected. In addition, proteins related to the
\end{abstract}

Communicated by M. Hajduch.

Electronic supplementary material The online version of this article (doi:10.1007/s11738-017-2416-7) contains supplementary material, which is available to authorized users.

Aleksandra Bocian

bocian@prz.edu.pl

1 Department of Biotechnology and Bioinformatics, Faculty of Chemistry, Rzeszow University of Technology, Powstańców Warszawy 6 Ave, 35-959 Rzeszow, Poland stress (especially oxidative) and defense, protein, and secondary metabolism were overexpressed. The results indicate that methyl jasmonate and cholesterol elicited a defense reaction at the proteome level as a response to stress. The usefulness of 2-DE method for identification of proteins related with species-specific metabolic pathways is restricted. Integration of transcriptome data with proteomic analysis improved annotation process.

Keywords Trigonella foenum-graecum L. · 2-D electrophoresis · Plant proteomics - Stress and defense

\section{Introduction}

Fenugreek (Trigonella foenum-graecum L.) is an annual plant of family Fabaceae widely distributed throughout the world. This wild or cultivated crop is commonly used as a traditional food or medicine due to anti-diabetic, hypocholesterolaemic, and anti-microbial effects (Mehrafarin et al. 2011). Fenugreek is a source of saponins (i.e., diosgenin, gitogenin, and tigogenin), alkaloids (i.e., trigonelline, gentianine, and choline), flavonoids (i.e., apigenin, luteolin, quercetin, and vitexin), steroids (i.e., cholesterol and sitosterol) and volatile oils (Snehlata and Payal 2012). One of the most important compounds of fenugreek is diosgenin that controls metabolism of cholesterol, and shows anticancer and anti-inflammatory activities. Diosgenin also serves as intermediate for synthesis of sex hormones and oral contraceptives (Raju and Rao 2012; Patel et al. 2012).

The changes in a content of secondary metabolites (i.e., saponins and flavonoids) may result from a range of abiotic and biotic stimuli including herbivorous attack or pathogenic infection (Szakiel et al. 2011; Falcone Ferreyra et al. 
2012). Receptors, which are situated in plasma membrane, recognized an elicitor and activated signal transduction pathway. Next, the secondary messengers, e.g., jasmonates, ethylene, and salicylic acid, activated the expression of defense genes including the genes which are involved in synthesis of secondary metabolites (Lambert et al. 2011). Methyl jasmonate was used to induce production of diosgenin in the seedlings of fenugreek (De and De 2011).

Saponins also play role in plant growth regulation. It has been reported that production of a-galactosidase activity, which is needed to germinate, was inhibited by diffusible saponin substances (Faizal and Geelen 2013).

Proteomic studies have appeared as leading tools providing answers in field of plant physiology and development. Procedures based on two-dimensional gel electrophoresis (2-DE) and mass spectrometry (MS) have become one of the most powerful techniques of plant proteomics (Nordhoff et al. 2001; Weiss and Görg 2007; Bocian et al. 2011; Correia et al. 2012). Combination relationships of protein populations, global protein identification along with internal patterns analysis, have ensured new insights into the connection of biochemical processes of different proteomes (Correia et al. 2012). The current status of proteomic research in legumes steps over the border of generating proteome reference maps, and now allows for understanding of key proteins answering for adaptation under the countless stress environments of abiotic and biotic nature (Rathi et al. 2016).

Plant has to contend with multiple abiotic and biotic factors. During the evolution, they have developed specific mechanisms enabling them to adapt and survive stressful events. After exposure to stress factor, plants activate specific ion channels and kinase cascades, phytohormones (salicylic acid, jasmonic acid, abscisic acid, and ethylene), and accumulate reactive oxygen species (ROS). To minimize the biological damage which is caused by stress, plants reprogrammed the genetic machinery, resulting in increase in plant tolerance and suitable defense reactions (Rejeb et al. 2014). Phytohormones play central role in abiotic and biotic stress signaling (Fraire-Velázquez et al. 2011). Jasmonic acid is involved in many different plant processes including storage, growth, reproduction, and senescence. It is activated in response to herbivory and plays important role in plant defense (Karban and Kuć 1999).

Within the current study, we provide the first proteomic data on reaction of fenugreek plants induced with methyl jasmonate and cholesterol. The aim of the study was to identify proteins differentially expressed after treatment of plants with (a) methyl jasmonate as the elicitor of diosgenin synthesis and plant defense response and (b) cholesterol as the precursor of steroidal saponins biosynthesis. To achieve this purpose, we induced in vitro cultures of fenugreek by elicitors listed above, and we identified and quantified a diosgenin as steroidal saponin representative. Plant producing extreme amounts of diosgenin was used to comparison protein using 2-DE and differentially expressed proteins were identified by the use of mass spectrometry MALDI-ToF/ToF. This approach allowed knowing reaction in fenugreek, a non-model plant, in response to stress and secondary biosynthesis.

\section{Materials and methods}

\section{Plant material}

Seeds of Trigonella foenum-graecum (Accession No. 19271) were obtained from Botanic Garden in Bonn (Germany). Seeds were sterilized by soaking in $70 \%$ ethanol for $2 \mathrm{~min}$ and then in a $30 \% \mathrm{v} / \mathrm{v}$ Domestos ${ }^{\circledR}$ solution for $30 \mathrm{~min}$. They were rinsed several times in sterile water before being germinated on a Murashige and Skoog (1962) agar medium containing 3\% sucrose. After germination, the plantlets were transferred onto fresh Murashige-Skoog agar medium and maintained at $24{ }^{\circ} \mathrm{C}$ with a 16-h light photoperiod. After 6 months, plants were treated with methyl jasmonate $(\mathrm{MeJ})\left(100 \mu \mathrm{L} \mathrm{L}^{-1}\right)$ and cholesterol (CHL) $\left(100 \mu \mathrm{g} \mathrm{L}^{-1}\right)$ to induce accumulation of diosgenin. Plants were sprayed with $10 \%$-ethanol solutions of induction factors and control plants were treated only by $10 \%$ ethanol. Then, plants were harvested on $1 \mathrm{st}, 3 \mathrm{rd}$, and 6 th days after spray, frozen in liquid nitrogen, and stored at $-80^{\circ} \mathrm{C}$.

\section{Extraction and identification of diosgenin}

Diosgenin was extracted with a liquid phase according to Savikin-Fodulovic et al. (1998) with modifications. Plant material was hydrolyzed with $1 \mathrm{M}$ sulfuric acid in $70 \%$ isopropanol for $6 \mathrm{~h}$ under reflux. In the next step, water was added and obtained solution was extracted three times with hexane and finally washed with $1 \mathrm{M} \mathrm{NaOH}$ and distilled water. Organic phase was evaporated to dryness in vacuum concentrator.

Diosgenin standard was purchased from Sigma-Aldrich. Unless specified otherwise, all chemicals were of analytical reagent grade and solvents were of HPLC grade. Water was purified using Milli-Q system (Merck Millipore).

Diosgenin was identified by ultra-performance liquid chromatography coupled with mass spectrometry with triple quadrupole. UPLC analyses were performed using a Shimadzu apparatus on a Kinetex C-18 RP column $(50 \mathrm{~mm} \times 2.1 \mathrm{~mm}$ I.D., $1.7 \mu \mathrm{m})$. The isocratic solvent system was $85 \%$ methanol, the flow rate was set at $0.6 \mathrm{~mL} \mathrm{~min}^{-1}$, and the column temperature was 
maintained at $35{ }^{\circ} \mathrm{C}$. The injection volume was $1 \mu \mathrm{L}$. All samples were dissolved in $1 \mathrm{~mL}$ of methanol. AB Sciex QTRAP 4500 was equipped with an electrospray ion source operating in positive ion. For targeted metabolites, we used very sensitive multiple reaction monitoring (MRM) method. For diosgenin transitions, $m / z 415.3 \rightarrow$ 271.20 and $\mathrm{m} / \mathrm{z} 415.3 \rightarrow 253.19$ were detected. For calculation of the concentration of diosgenin, calibration curve was used. The correlation coefficient of calibration curve was $r^{2}=0.997$. Measurements were taken in three replicates. ANOVA analysis was performed to test significance of differences between means in STATISTICA (Statistica 2010).

\section{Protein extraction, quantification, and 2-DE separation}

Samples with the highest and the lowest (control) contents of diosgenin were selected for protein extraction according to Hurkman and Tanaka (1986). The protein concentration in extracts diluted in thiourea sample solution [7 M urea, $2 \mathrm{M}$ thiourea, 2\% Nonidet P-40 substitute, 2\% IPG buffer $\mathrm{pH}$ range $3-10$, and $40 \mathrm{mM}$ dithiothreitol (DTT)] was determined by 2D Quant kit (GE Healthcare) with using bovine serum albumin as the standard.

The extracted protein $(550 \mu \mathrm{g})$ samples were individually loaded onto $24 \mathrm{~cm}$ Immobiline DryStreap Gel $(\mathrm{pH}$ 3-10). Isoelectric focusing was performed at $50 \mu \mathrm{A}$ per strip at $20^{\circ} \mathrm{C}$ using the Ettan IPGphor II (GE Healthcare) programmed as follows: $12 \mathrm{~h}$ of passive rehydration and $10 \mathrm{~h}$ of focusing at $1 \mathrm{~h}$ with $500 \mathrm{~V}, 2 \mathrm{~h}$ with $1000 \mathrm{~V}, 3 \mathrm{~h}$ with $8000 \mathrm{~V}$, and $4 \mathrm{~h}$ with 10,000 V. The strips were then equilibrated twice successively for $15 \mathrm{~min}$ in an equilibration solution [75 mM Tris-HCl, $6 \mathrm{M}$ urea, 29.3\% (v/v) glycerol, $2 \%(\mathrm{w} / \mathrm{v}) \mathrm{SDS}$, and $0.002 \%$ bromofenol blue], supplemented with $1 \%$ (w/v) DTT (the first equilibration) and $2.5 \%(\mathrm{w} / \mathrm{v})$ iodoacetamide (the second equilibration). The second dimension was performed as SDS-PAGE using $12 \%$ (v/v) resolving gel (EttanDALTsix, GE Healthcare). Gels were stained with Coomassie Brilliant Blue G250 and images were acquired on ImageScannerIII. All gels were prepared in three independent technical replications. Bioinformatic analyses of the gels were performed in ImageMaster 2D Platinum program. Spots were detected, normalized, and matched through the entire matchset. Spots presenting more than 1.5-fold changes of $\%$ Vol in effector-treated samples against control samples and $p$ values lower than 0.05 were considered to be differentially expressed. Exclusively spots detected in treated or control gels as well as spots detected in both treated and control gels but with accumulation more than 1.5 -fold change of $\% \mathrm{Vol}$, were selected to identification.

\section{Protein identification using MALDI-ToF}

The spots were successively subjected to a series of washes in solutions: $50 \mathrm{mM}$ ammonium carbonate, acetonitrile, ammonium carbonate:acetonitrile (1:1), and acetonitrile. Spots were dried and subjected to reduction (45 min at $56{ }^{\circ} \mathrm{C}, 0.15 \%$ of DTT in ammonium carbonate) and alkylated (30 $\mathrm{min}$ in the darkness, $1 \%$ solution of iodoacetamide in ammonium carbonate). The gels were washed again with a mixture of ammonium carbonate and acetonitrile (1:1), acetonitrile, and dried. The dried gel was digested overnight at $37{ }^{\circ} \mathrm{C}$ after adding $0.2 \mu \mathrm{g}$ of trypsin. After the digestion reaction was quenched by the addition of acetonitrile, the samples were sonicated and the liquid fraction was transferred to new tubes.

For analysis with MALDI-ToF (matrix-assisted laserdesorbed ionization-time-of-flight), $0.5 \mu \mathrm{L}$ protein sample was directly imposed on MALDI target, mixed with $1 \mu \mathrm{L}$ $\alpha$-cyano-4-hydroxycinnamic acid matrix, and dried out. The samples were analyzed using MALDI-ToF/ToF (Bruker Daltonics) and mass spectra were calibrated using the peptide standard calibration as external patterns (Peptide Calibration Standards II, Bruker Daltonics). The sample ionization was carried out with laser beam at $337 \mathrm{~nm}$. The analyzer operated in the reflective mode and positive ions were recorded in the mass range between 700 and $3500 \mathrm{Da}$. The received monoisotopic peptide mass maps were compared to protein databases NCBInr, SwissProt, and MSDB using the Mascot search engine (Matrix Science Inc.) with criteria: a peptide mass tolerance of MS 0.1-0.5 Da, and allowance for up to one trypsin miscleavage, constant amino-acid modifications-cysteine carbamidomethylation and variable modification-methionine oxidation, and confidence level 95\%. Individual peptides selected from mass spectrum were sequenced using LIFT ion source by laser-induced dissociation (LID). Tandem mass spectrum was analyzed as described above. The search parameters for MS/MS data were identical as those used for MALDI-ToF analyses. The only exception was mass tolerance which was set to 0.4 Da for MS mode and 0.2 Da for MS/MS mode.

\section{Protein identification using tBLAST}

To get information on fenugreek-specific proteins not annotated using Mascot, we exploited database of speciesspecific transcripts. Combinations of peptides corresponding to fragment masses were queried against four databases of translated transcripts (developed upon treatment with cholesterol, methyl jasmonate, squalene, and control). BLOSUM62 and PAM30 matrixes were used in local BLAST with tblastix module in CLC Main Workbench v.6.9.2. DNA sequences corresponding to the best hits were 
retrieved from databases and further used to extract contigs, and consensus sequences. For each spot, best hits were treated as random and independent thus corresponding E-values were multiplied for sequences targeting single contig. Consensus sequences with the lowest cumulative E-value were functionally annotated at Blast2GO v.3.2.7.

\section{Results}

\section{Change in diosgenin content}

Fenugreek plants were treated with methyl jasmonate (MeJ) and cholesterol (CHL) to activate genes and proteins involved in biosynthesis of diosgenin. Changes of the levels of this steroidal saponin were measured in fresh weight of plants after the treatments vs control. Concentrations of diosgenin were not significantly different in subsequent days of culture, but depended on treatment $(p=0.036)$ and interaction of treatment with time $(p=0.015)$. The highest differences in content of diosgenin were observed on 6th day. Average contents of diosgenin in MeJ and CHL-treated plants (310.3 and $120.3 \mu \mathrm{g} \mathrm{g}^{-1}$ fresh weight, respectively) were enhanced about five, and twofold when compared to control (Fig. 1).

\section{Identification of protein using 2-DE and MALDI- ToF}

The proteome of $T$. foenum-graecum was profiled using 2-DE, and samples from 6th day after treatment methyl jasmonate and cholesterol were used. Gel after treatment: MeJ contains 222 spots and CHL 236 spots. Control gel includes 226 spots. The majority of spots are within the range $\mathrm{pI}=4-8$ and possessed molecular masses between 20 and $120 \mathrm{kDa}$.

Proteins from effector-treated and control were analyzed with using ImageMaster 2D Platinum software. The protein spots that revealed repetitive changes under MeJ (Fig. 2) and CHL treatment (Fig. 3) were selected and used for further analysis. A number of 41 spots for cholesterol and 63 spots for methyl jasmonate were differentially expressed including 19 and 34 proteins that presented higher $\%$ Vol (blue frames in Figs. 2, 3) after treatment with cholesterol and MeJ, respectively. Moreover, five spots were detected only in treated gels (green frames in Figs. 2, 3 ) and 14 spots solely in control gel (red frames in Figs. 2, 3). The differentially expressed protein spots were cut out, in-gel digested by trypsin, analyzed using tandem MS, and then identified after searching the MS/MS spectra using Mascot (Table 1). In case of MeJ and cholesterol treatments, 46 and 26 spots were successfully identified, respectively. A $27-37 \%$ of proteins, both in control and in treated plants, have no hits in Mascot database.

Among protein spots obtained after $\mathrm{MeJ}$ and $\mathrm{CHL}$ treatments, 19 and 9, respectively, were localized in chloroplast. Spots identified as the same protein were considered to be isoform, like ribulose bisphosphate carboxylase small chain $C$ (spots 265 and 266) in control gel to MeJ treatment, or translation from alternatively spliced mRNAs and post-translational modifications (chlorophyll $a-b$ binding protein $\mathrm{AB} 80$ (spots 184 and 198) in MeJ gel,
Fig. 1 Content of diosgenin in methyl jasmonate $(\mathrm{MeJ})$ and cholesterol (CHL) treated plants vs control

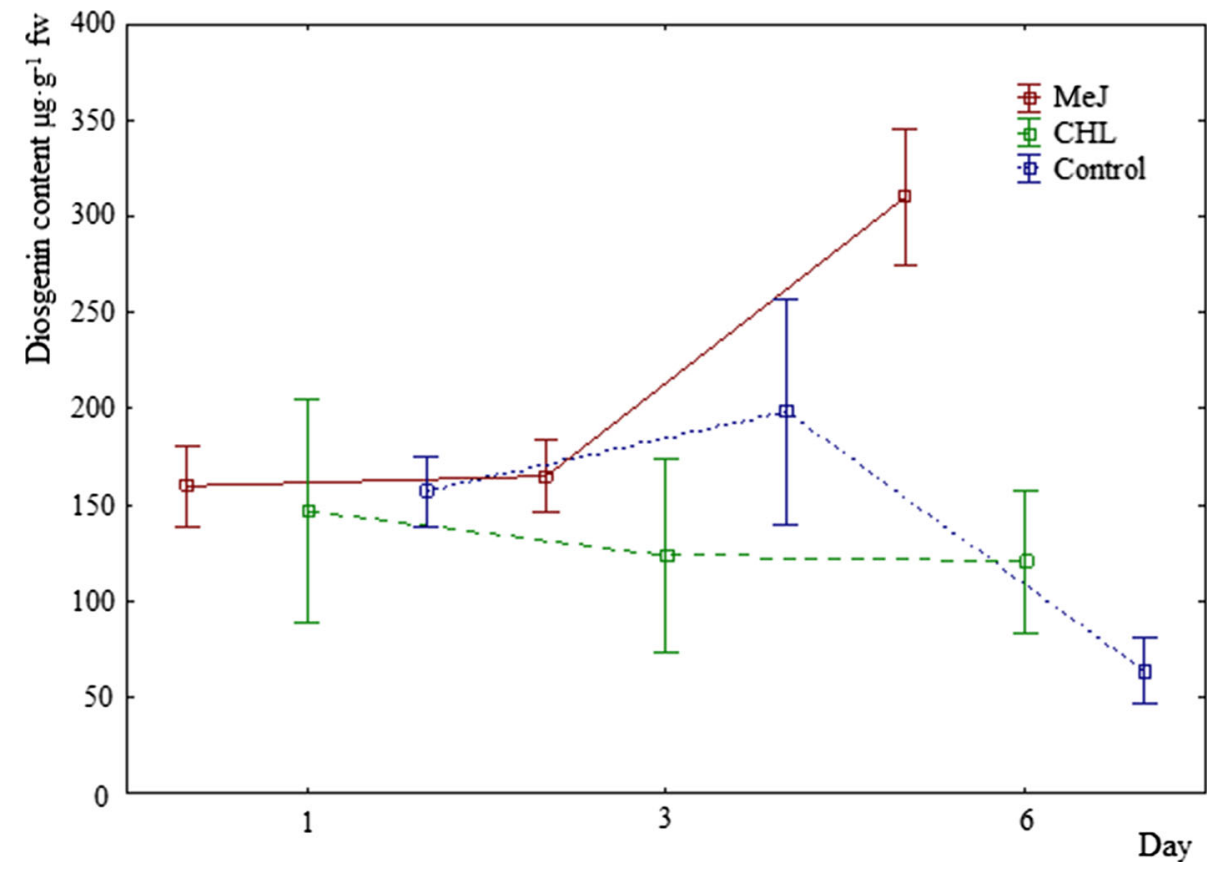




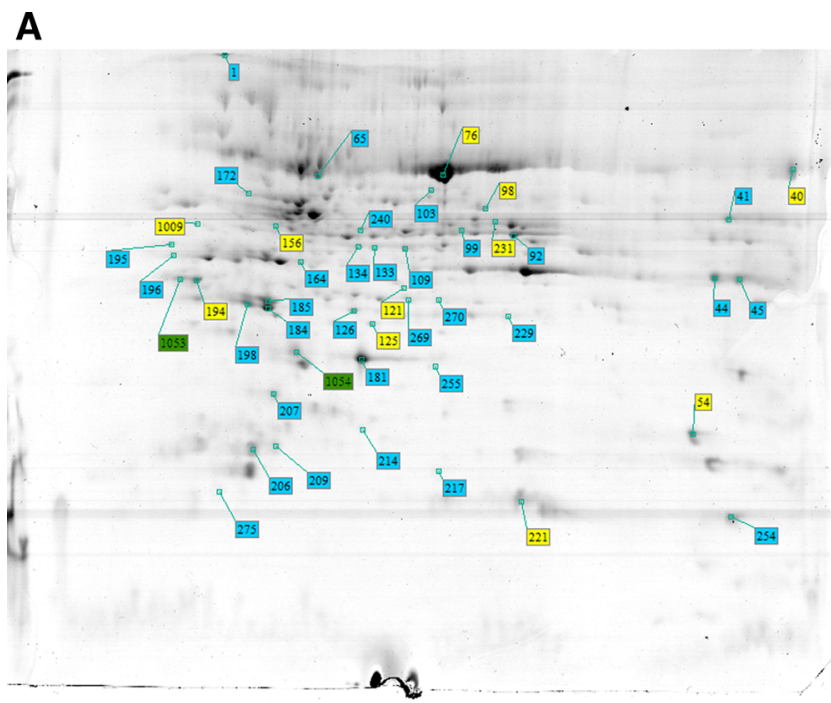

Fig. 2 2D-gel images of protein spots obtained after treatment of methyl jasmonate (a) and comparison with control gel (b). The numbers in the frames represent the numbers of spots. Colors of the

A

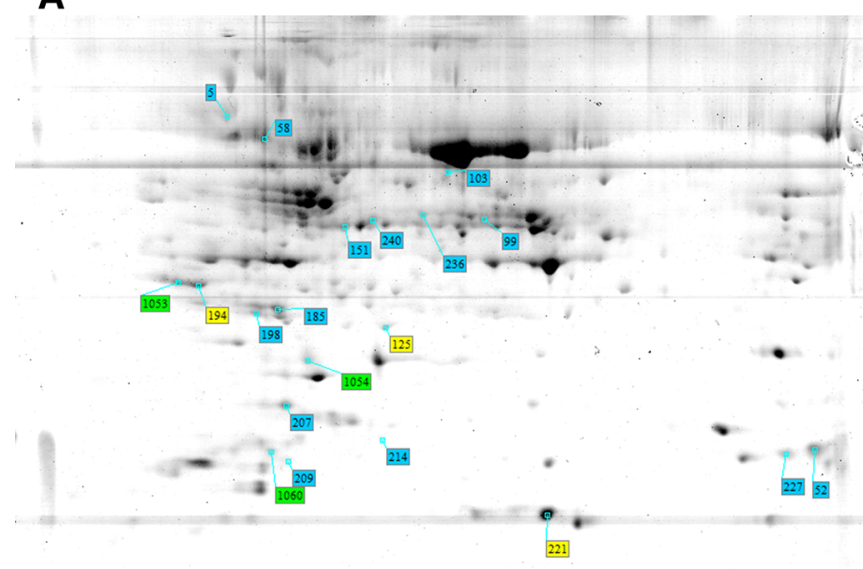

Fig. 3 2D-gel images of protein spots obtained after treatment of cholesterol (a) and comparison with control gel (b). The numbers in the frames represent the numbers of spots. Colors of the frames

fructose-bisphosphate aldolase 1 (spots 236 and 240) in CHL gel).

To subsequent investigate, the identified differentially expressed proteins were classified according to main function based on UniProt database (Fig. 4). The MeJtreated proteins were involved in photosynthesis $(40 \%)$, metabolism $(29 \%)$, stress and defense $(20 \%)$, protein metabolism (12\%), energy (8\%), and secondary metabolism $(4 \%)$. Besides, $8 \%$ were represented by membrane and transport, and transcription-related. In CHL treatment gel, we classified protein to photosynthesis $(20 \%)$, protein metabolism (20\%), stress and defense (20\%), metabolism
B

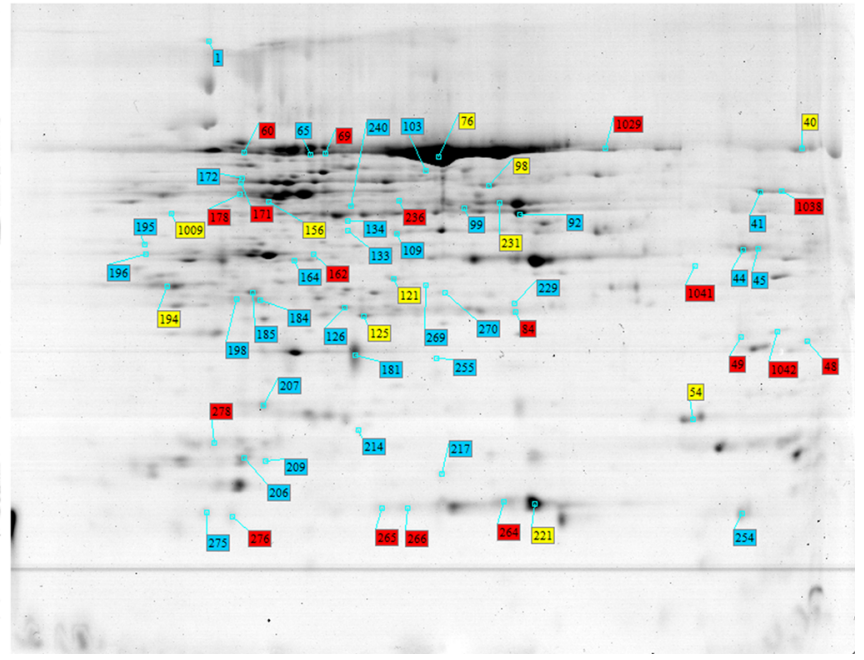

frames denote: red occur only in control gel; yellow higher accumulation in control gel; blue higher accumulation in tested gel; green occur only in tested gel

B

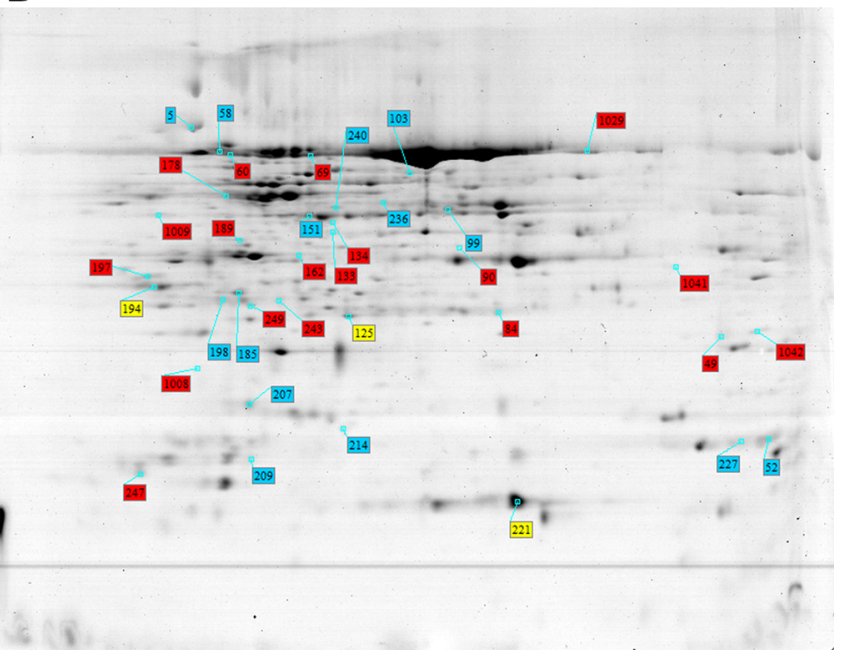

denote: red occur only in control gel; yellow higher accumulation in control gel; blue higher accumulation in tested gel; green occur only in tested gel

(7\%), secondary metabolism (7\%), and transcription-related (7\%) (other in the diagram). Analysis of control gels reveals that proteins belong in the largest group to photosynthesis, followed by stress and defense, energy, metabolism, and protein metabolism.

Interestingly, that after MeJ treatment level of proteins involved in stress and defense, metabolism, and protein metabolism clearly increased when compared to the control. Moreover, the relative amount of proteins associated with energy production and process of photosynthesis decreased. Similarly, in cholesterol-treated plants, the number of proteins involved in energy and smaller extent 


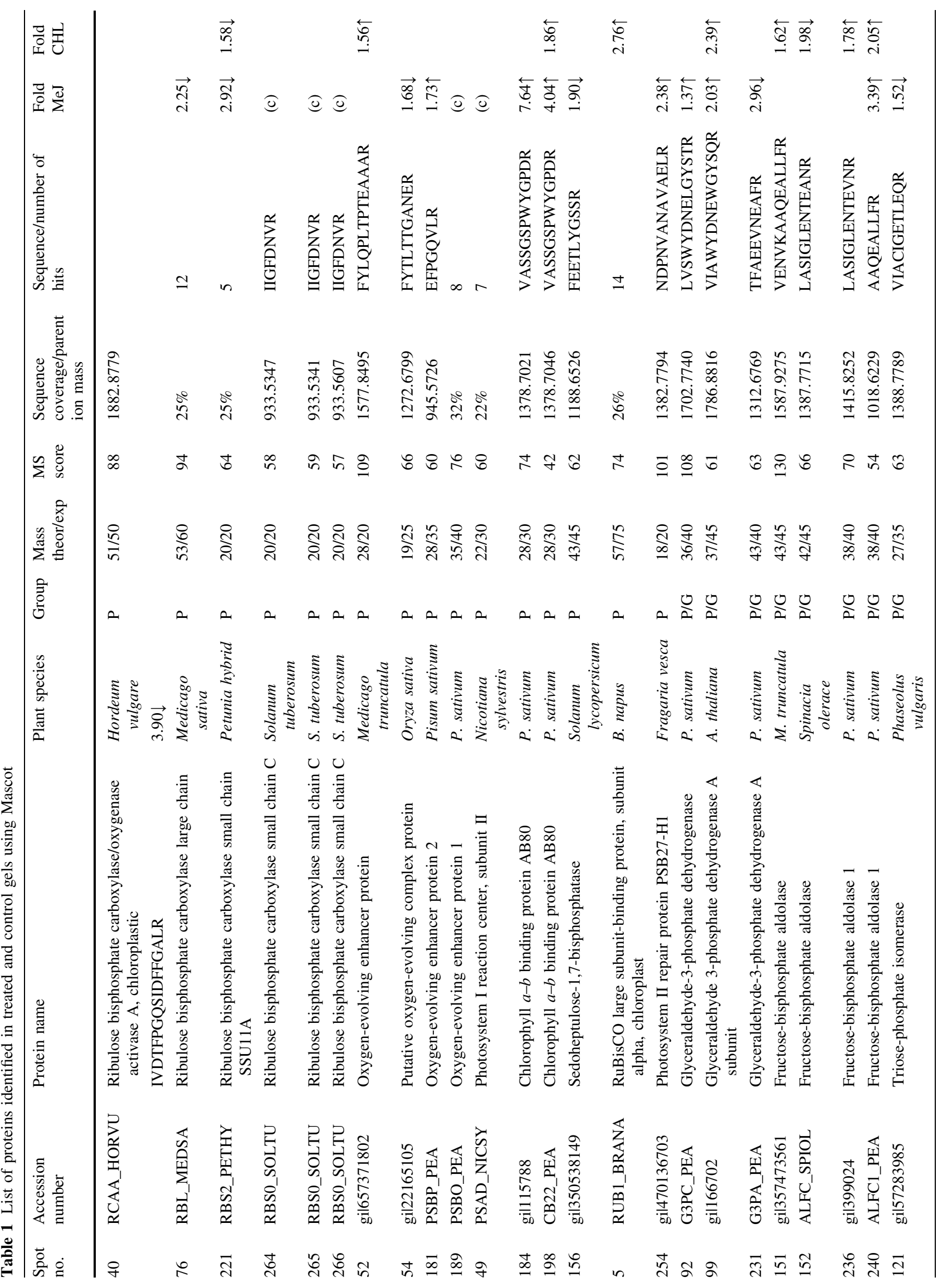




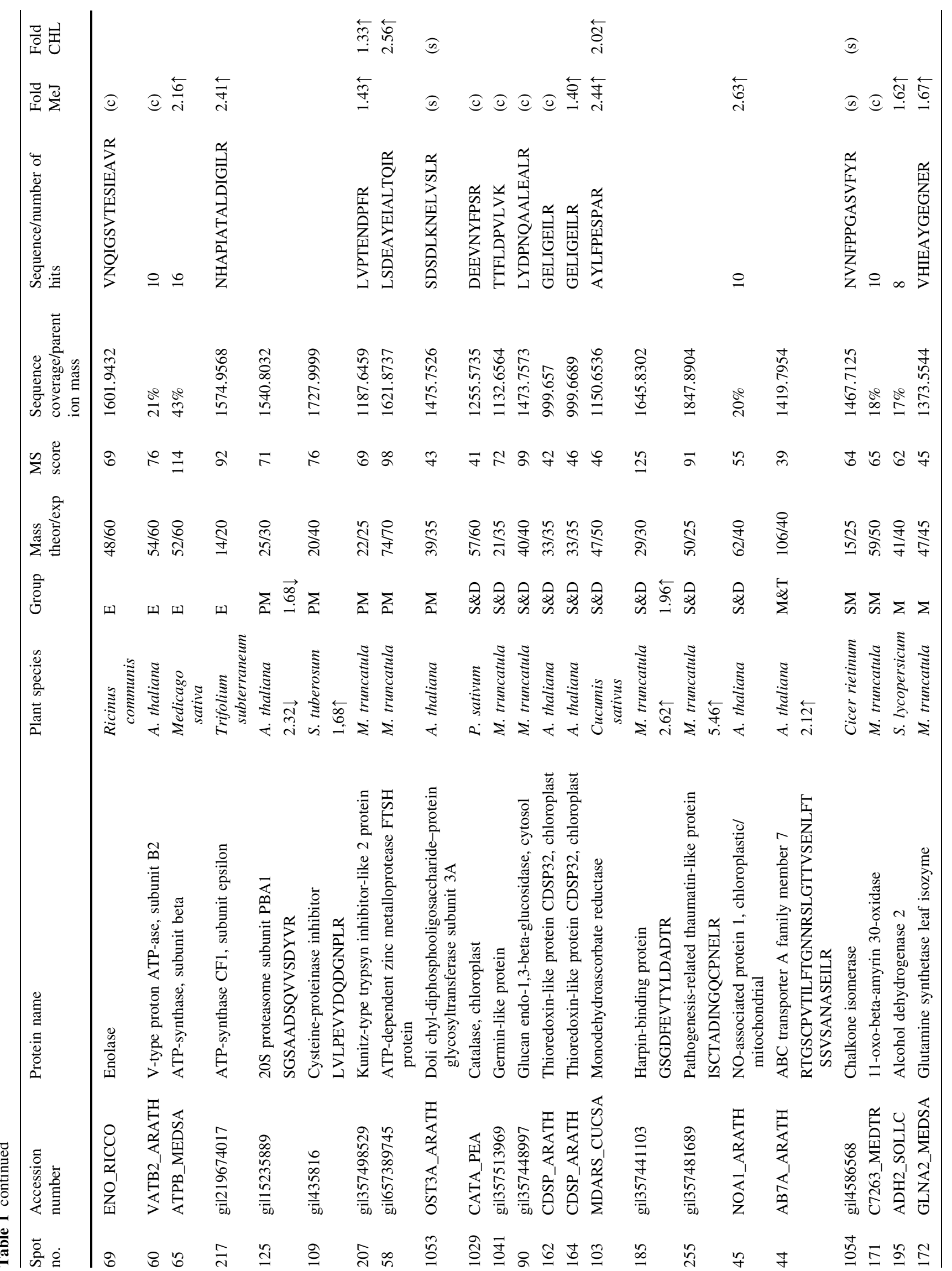




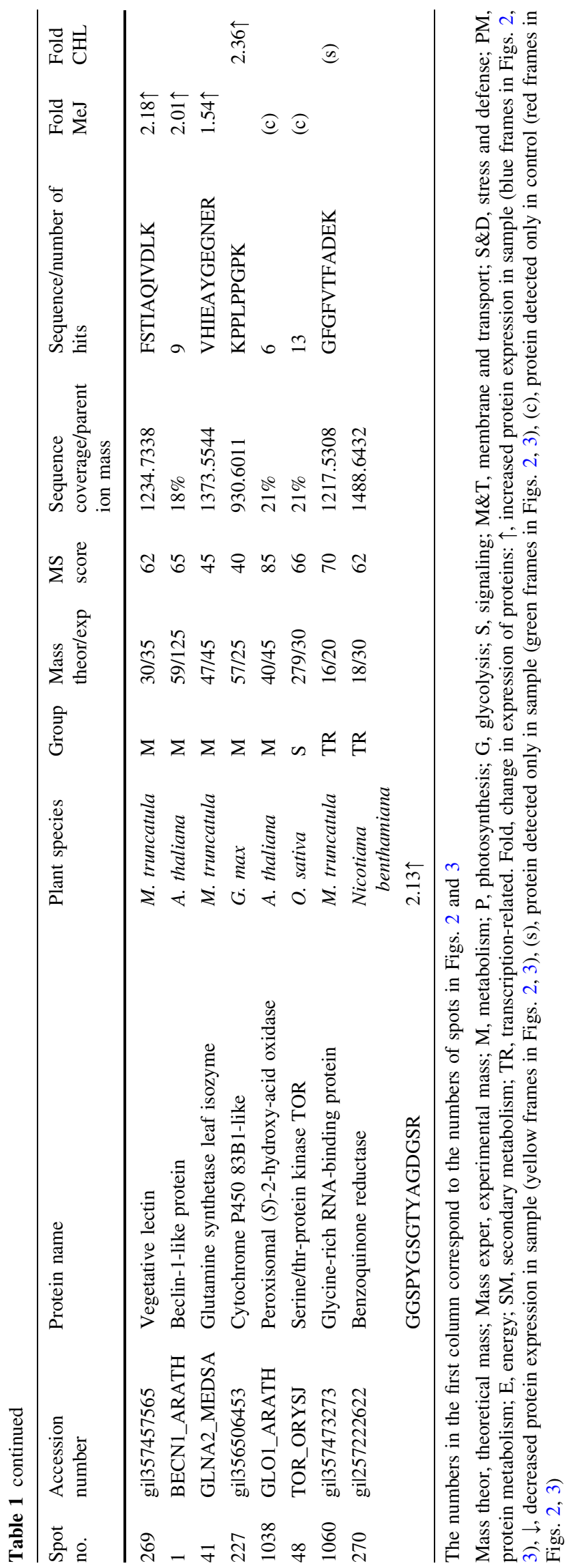

light-dependent reactions of photosynthesis decreased. The fraction of proteins involved in processes of protein and secondary metabolism increased compared to controls. These findings indicate that basic processes like photosynthesis, metabolism, protein metabolism, stress, and defense play an important role in methyl jasmonate and cholesterol-treated plants. Following MeJ and cholesterol treatments, two proteins related with secondary metabolism were identified, i.e., 11-oxo-beta-amyrin 30-oxidase and chalkone isomerase.

Peptide sequences were available for 11 spots that could not be annotated using Mascot database. Four spots (229, 178,196 , and 96) with single ion mass were not identified using tblast approach (Table 2). In case of remaining proteins, integration of proteomic and transcriptomic data leads to successful identification. Functional annotation was not available for MACPF domain protein. New annotated proteins were involved in reaction to stress, transport, and metabolic processes. The most interestingly, we found kinase (spot 126) involved in flavonoid biosynthesis. The usefulness of 2-DE method for identification of proteins related with species-specific metabolic pathways is restricted, but integration of proteomic data with transcriptome sequencing can be explored to improve annotation process.

\section{Discussion}

\section{Effects on photosynthesis and carbon metabolism}

The abundance of proteins involved in photosynthesis was affected by various effectors. Photosynthesis is the most important phenomenon, which significantly contributes to the plant growth and development (Ashraf and Harris 2013). We identified proteins which were up-regulated after various treatments and are involved in light and dark reactions, e.g., ribulose bisphosphate carboxylase small and large chain (RuBisCO) (spots 40, 76, 221, 264, 265, and 266), oxygen-evolving enhancer protein (spots 52, 54, 181, and 189), photosystem I reaction center (spot 49), chlorophyll $a-b$ binding protein AB80 (spots 184 and 198), sedoheptulose-1,7-bisphosphatase (spot 156), glyceraldehyde-3-phosphate dehydrogenase (spots 92, 99, and 231), fructose-bisphosphate aldolase (spots 151, 152, 236, and 240), triose-phosphate isomerase (spot 121), and enolase (spot 69).

The photosystems, primarily photosystem II (PSII) in combination with oxygen-evolving complex, also generation of ATP, and the processes of carbon assimilation are the major stress-sensitive components in the photosynthetic apparatus (Allakhverdiev et al. 2008). Oxygen-evolving enhancer protein was overexpressed both in treated and 

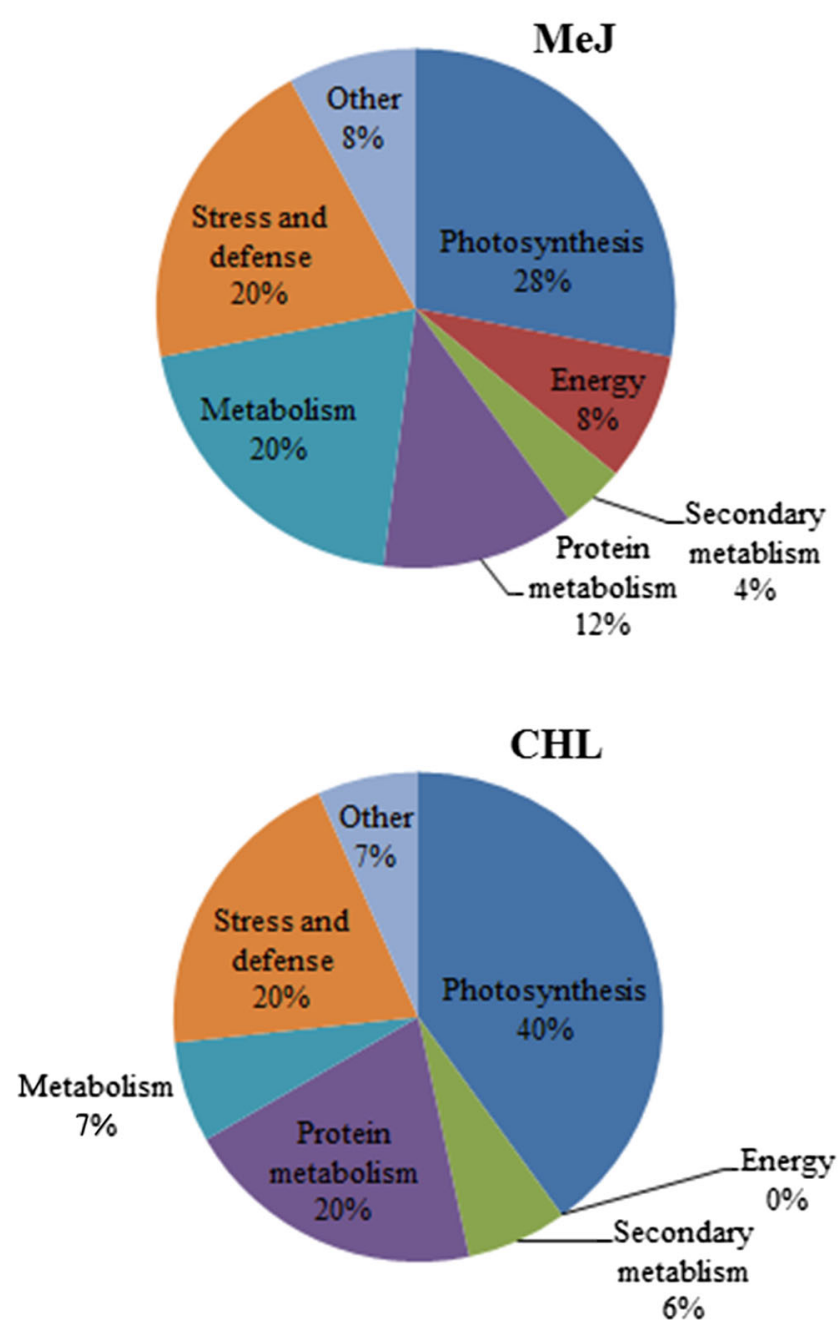

Fig. 4 Classification of identified proteins in treated plants and control

control plants, while higher amounts of ribulose bisphosphate carboxylase small and large chains were found in control. In turn, chlorophyll $a-b$ binding protein AB80 was overexpressed in treated plants. Photosynthesis cascades are strongly interdependent with the accumulation of $\mathrm{RuBisCO}$ and other photosynthesis-related proteins (Nouri et al. 2015). In our study, also RuBisCO large subunitbinding protein subunit alpha (spot 5) which belongs to chaperon family, and photosystem II repair protein PSB27H1 (spot 254) had elevated expression in treated plants. It indicated their possible role in response to stress and protection of important photosynthetic proteins.

We identified proteins involved in ATP production processes. In control, V-type proton ATP-ase subunit B2 (spot 60) was identified, while two ATP-synthases: subunit beta (spot 65) and CF1 subunit epsilon (spot 217) were overexpressed in greater amount in MeJ-treated plants. Response to stress demands comparatively high energy
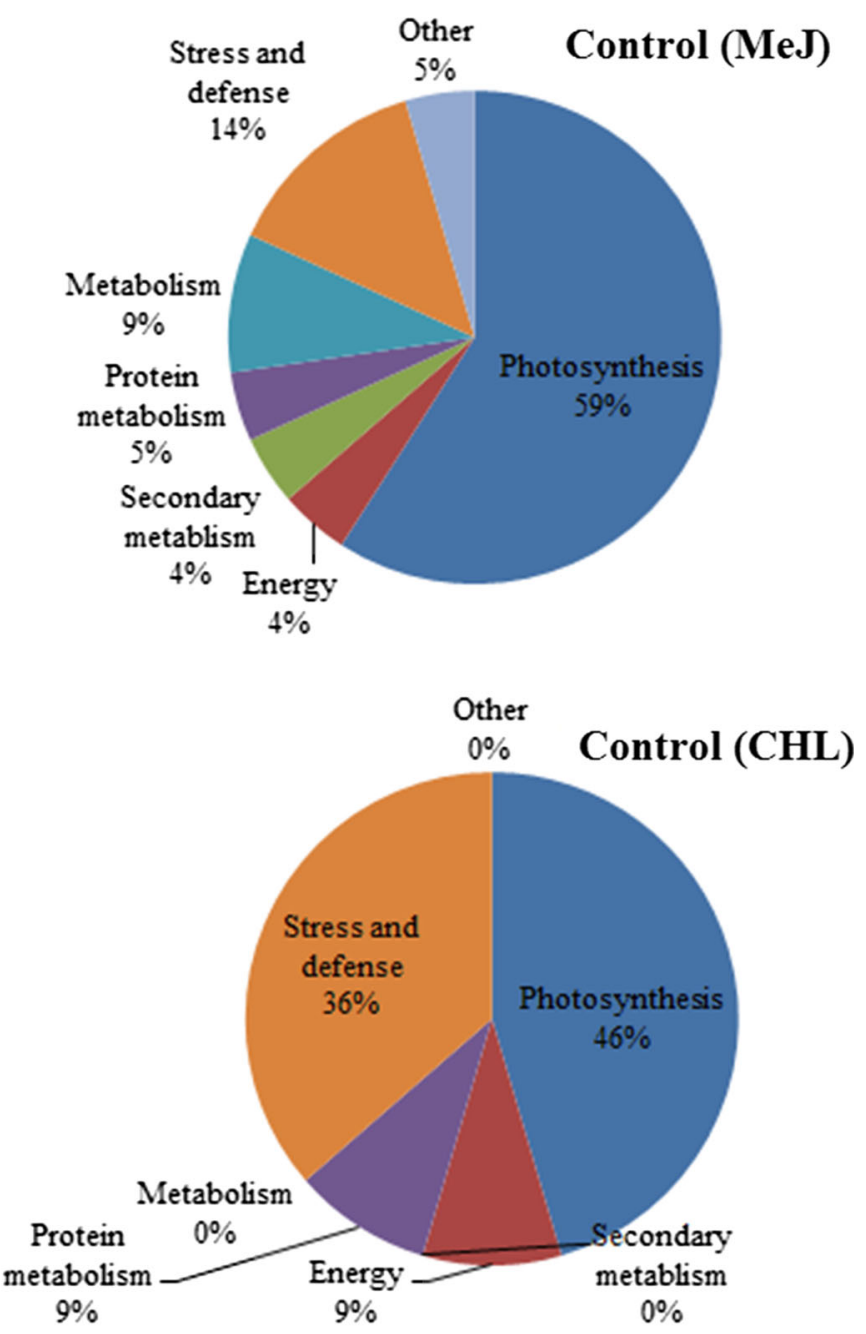

costs as indicated by thorough changes in energy metabolism, including $\beta$ subunit of $C F 1$ complex of mitochondrial ATP-synthase, indicating an increased requirement for energy (Kosová et al. 2014).

Glycolysis is important stage in the manufacture of energy and carbon skeletons of primary and secondary metabolites. Some proteins active in glycolytic pathway were differentially regulated under our treatment conditions. Glyceraldehyde-3-phosphate dehydrogenase and fructose-bisphosphate aldolase of the Calvin cycle had strong responses to the effectors. Glyceraldehyde-3-phosphate dehydrogenase has been proposed to play role in ROS-mediated signaling in plants (Chattopadhyay et al. 2011). Sedoheptulose-1,7-bisphosphatase, which was overexpressed in MeJ-treated and control plants, is an essential regulator of the Calvin cycle, and has directly influences on the rate of photosynthesis. Expression of this gene is affected by various factors as development, light, 
Table 2 List of differentially accumulated proteins classified as 'unknown' and identified in result of comparisons with transcriptome

\begin{tabular}{|c|c|c|c|c|c|c|c|c|c|}
\hline $\begin{array}{l}\text { Spot } \\
\text { no. }\end{array}$ & $\begin{array}{l}\text { Accession } \\
\text { number }\end{array}$ & Protein name & $\begin{array}{l}\text { Plant } \\
\text { species }\end{array}$ & GO terms & $\begin{array}{l}\text { Parent ion } \\
\text { mass }\end{array}$ & $\begin{array}{l}\text { Number of } \\
\text { hits/contigs }^{\text {a }}\end{array}$ & E-score & $\begin{array}{l}\text { Transcript } \\
\text { database }\end{array}$ & Fold \\
\hline \multirow[t]{2}{*}{126} & 922375682 & $\begin{array}{l}\text { Transmembrane } \\
9 \text { superfamily } \\
\text { protein }\end{array}$ & $\begin{array}{l}\text { M. } \\
\text { truncatula }\end{array}$ & $\begin{array}{l}\text { Integral component of } \\
\text { membrane }\end{array}$ & \multirow{2}{*}{$\begin{array}{r}1238.6731 ; \\
1322.7298 \\
1618.8567 \\
1832.9422\end{array}$} & \multirow[t]{2}{*}{$54 / 18$} & $6.87 \mathrm{E}-13$ & $\mathrm{cms}$ & \multirow[t]{2}{*}{$1.53 \uparrow$} \\
\hline & 922400062 & $\begin{array}{l}\text { Serine/threonine } \\
\text { kinase }\end{array}$ & $\begin{array}{l}\text { M. } \\
\quad \text { truncatula }\end{array}$ & $\begin{array}{l}\text { Chloroplast, protein } \\
\text { kinase activity, ATP } \\
\text { binding, protein } \\
\text { phosphorylation, } \\
\text { response to sucrose, } \\
\text { flavonoid } \\
\text { biosynthetic process, } \\
\text { response to UV-B }\end{array}$ & & & $6.34 \mathrm{E}-10$ & $\mathrm{k}$ & \\
\hline 134 & 357520217 & $\begin{array}{l}\text { Membrane } \\
\text { attack } \\
\text { complex/ } \\
\text { perforin } \\
\text { (MACPF) } \\
\text { domain protein }\end{array}$ & $\begin{array}{l}\text { M. } \\
\quad \text { truncatula }\end{array}$ & - & 1557.8051 & $28 / 17$ & $2.68 \mathrm{E}-06$ & $\mathrm{cms}$ & $4.24 \uparrow$ \\
\hline 84 & 922380315 & $\begin{array}{l}\text { ARM repeat } \\
\text { RING/U-box } \\
\text { protein }\end{array}$ & $\begin{array}{l}\text { M. } \\
\quad \text { truncatula }\end{array}$ & $\begin{array}{l}\text { Ubiquitin-protein } \\
\text { transferase activity, } \\
\text { ligase activity, } \\
\text { protein } \\
\text { ubiquitination }\end{array}$ & $\begin{array}{l}1475.7372 \\
1489.7282 \\
900.5120\end{array}$ & $26 / 16$ & $1.54 \mathrm{E}-06$ & $\mathrm{cms}$ & (c) \\
\hline 194 & 125662829 & Beta-tubulin & $\begin{array}{l}\text { Spinacia } \\
\text { oleracea }\end{array}$ & $\begin{array}{l}\text { Cytoplasm, } \\
\text { microtubule, GTPase } \\
\text { activity, metabolic } \\
\text { process }\end{array}$ & $\begin{array}{c}1069.6420 \\
1560.8533\end{array}$ & $1 / 1$ & $2.31 \mathrm{E}-01$ & $\mathrm{~m}$ & $2.15 \downarrow$ \\
\hline 197 & 922334060 & $\begin{array}{l}\text { AT-hook motif } \\
\text { nuclear- } \\
\text { localized } \\
\text { 7-like }\end{array}$ & $\begin{array}{l}\text { M. } \\
\quad \text { truncatula }\end{array}$ & DNA binding & $\begin{array}{r}1193.7069 \\
132.6790 \\
1493.8356\end{array}$ & $43 / 23$ & $1.62 \mathrm{E}-12$ & cmsk & (c) \\
\hline 243 & 922334060 & $\begin{array}{l}\text { Tiosephosphate } \\
\text { isomerase, } \\
\text { chloroplastic }\end{array}$ & $\begin{array}{l}\text { Cicer } \\
\text { arietinum }\end{array}$ & $\begin{array}{l}\text { Gluconeogenesis, } \\
\text { response to salt } \\
\text { stress, indoleacetic } \\
\text { acid biosynthetic } \\
\text { process, calcium ion } \\
\text { transport }\end{array}$ & $\begin{array}{c}1096.6158 \\
1647.9230\end{array}$ & $28 / 16$ & $4.52 \mathrm{E}-12$ & cmsk & (c) \\
\hline 249 & 357436839 & $\begin{array}{l}\text { Transcriptional } \\
\text { corepressor } \\
\text { leunig-like } \\
\text { protein }\end{array}$ & $\begin{array}{l}\text { M. } \\
\quad \text { truncatula }\end{array}$ & $\begin{array}{l}\text { Transferring glycosyl } \\
\text { groups, metabolic } \\
\text { process }\end{array}$ & $\begin{array}{l}1188.7079 ; \\
1309.7895 \\
1521.8715 \\
879.4592 \\
967.5285\end{array}$ & $77 / 47$ & $4.08 \mathrm{E}-09$ & cmsk & (c) \\
\hline
\end{tabular}

a Number of transcripts matched in four databases of transcripts: methyl jasmonate (m), cholesterol (c), squalene (s), and control (k), Fold, change in accumulation of proteins: $\uparrow$, increased protein accumulation in sample, $\downarrow$, decreased protein accumulation in sample, (s), protein detected only in sample, (c), protein detected only in control

and levels of hexose sugars (Raines et al. 1999; Raines and Paul 2006).

Photosynthesis, glycolysis, and synthesis of energy are closely associated processes that affect functioning of cell. Changes in light reactions are linked with energy production and sugar level, and are recorded in different expression of respective proteins. Obtained results indicate that differentially expressed proteins involved in photosynthesis and carbon metabolism were significant part of a defense response induced by $\mathrm{MeJ}$.

\section{Protein metabolism}

In group of protein metabolism, we identified proteasome subunit beta type-6 (spot 125) in control plants. Higher accumulation in $\mathrm{MeJ}$ and cholesterol-treated plants was found for cysteine and/or aspartic-protease inhibitor (spot 109), Kunitz-type trypsyn inhibitor-like 2 protein (spot 207), ATP-dependent zinc metalloprotease FTSH protein (spot 58), and dolichyl-diphosphooligosaccharide-protein glycosyltransferase 3A (spot 1053). Proteasomes are 
multicatalytic complexes (14 $\alpha$ - and $14 \beta$-subunits) engaged in processes like protein degradation in processes induced by environmental stresses, senescence, cell death, or wounding (Etienne et al. 2000; Vítámvás et al. 2015; Nam et al. 2012). Increased level of this protein in control may reflect protein degradation processes associated with stress induced by $10 \%$ ethanol. Increased level of proteinase inhibitors (PIs) was detected in MeJ-treated samples. Proteinase inhibitors play a meaningful defensive role against pathogens and predators, and are induced in plants in response to injury or attack by pathogens or insects, and induced by jasmonic acid (Habib and Fazili 2007; Farmer et al. 1992; Kang et al. 2002). Kunitz-type inhibitors are produced under stress in leguminous plants, and inhibit serine proteases, trypsin, chymotrypsin, subtilisin, asparticprotease, and cathepsin D (Habib and Fazili 2007). ATPdependent zinc metalloprotease FTSH protein accumulated in potato leaf tissues in a response to wounding (Ryan 1990), and was also identified in cholesterol-treated fenugreek samples.

\section{Stress and defense-related proteins}

Besides the proteins involved in process of photosynthesis, stress- and defense-related proteins formed the second most active group. In response to abiotic and biotic stresses, plants generate reactive oxygen species (ROS) that, in elevated levels, cause oxidative stress (Caverzan et al. 2016). Scavenging or detoxification of overabundance ROS is reached by an effective antioxidative system consisting of both non-enzymatic as well as enzymatic antioxidants. The enzymatic antioxidants include catalase, superoxide dismutase, guaiacol peroxidase, and enzymes of ascorbate glutathione cycle such as monodehydroascorbate reductase, dehydroascorbate reductase, ascorbate peroxidase, and glutathione reductase (Sharma et al. 2012).

A number of stress related proteins were overexpressed in control fenugreek plants including chloroplast catalase (spot 1029), germin-like protein (spot 1041), glucan endo1,3-beta-glucosidase (spot 90), and thioredoxin-like protein CDSP32 (spot 162). Thioredoxin CDSP32 was also found in MeJ-treated sample (spot 164). Catalase is crucial during the oxidative stress for maintaining the redox balance and scavenges $\mathrm{H}_{2} \mathrm{O}_{2}$ produced in peroxisomes during $\beta$-oxidation of fatty acids, photorespiratory oxidation, and other enzyme systems (Sharma et al. 2012; Willekens et al. 1997). Germin-like proteins play critical roles in plant defense response to fungal, bacteria and virus infections, insect attack, chemical toxicities, and stress caused by salinity and drought (Wang et al. 2013; Komatsu et al. 2014). Glucan endo-1,3-beta-glucosidase degrades the beta-glucan, component of hemicelluloses which builds cell walls, and is accumulated in response to ABA, salt stress, and involved in the defense against pathogens ( $\mathrm{Li}$ et al. 2010, 2015). CDSP32 thioredoxin takes part in plastidic responses during oxidative stress (Rey et al. 2005).

Expression of monodehydroascorbate reductase (spot 103) and harpin-binding protein (spot 185) increased both in MeJ and CHL-treated plants. Monodehydroascorbate reductase is involved in elimination of $\mathrm{H}_{2} \mathrm{O}_{2}$ in ascorbateglutathione cycle (Noctor and Foyer 1998), and plays a significant role in fighting oxidative stress induced by environmental factors (Sharma et al. 2012; Caverzan et al. 2016). Harpin-binding proteins are well known as elicitors that induce numerously responses in plants, such as hypersensitive response, systemic acquired resistance, reinforcement of growth, and tolerance to drought, and induce defense mechanism in response to nitrogen stress (Song et al. 2010; Zhang et al. 2011).

In MeJ-treated plants, we found enhanced expression of pathogenesis-related thaumatin-like protein (spot 255), NOassociated protein 1 (spot 45), and $\mathrm{ABC}$ transporter $\mathrm{A}$ family member 7 (spot 44). Pathogenesis-related (PR) thaumatin-like proteins are induced and accumulate locally and often systemically in plant tissues in response to infection and various abiotic and biotic stresses (Hammerschmidt and Nicholson 1999). Beside stress stimuli, proteins of the PR5 family, also named thaumatin-like proteins, are induced by phytohormones (methyl jasmonate, salicylic acid, and abscisic acid) (Wang et al. 2010).

\section{Proteins involved in secondary metabolism}

The positive effect of MeJ on diosgenin production has been reported (De and De 2011). Similarly, cholesterol was applied for induction of steroidal saponins previously (Aasim et al. 2014). Two proteins involved in secondary metabolism were overexpressed in the fenugreek plants. Chalcone isomerase (spot 1054) was found exclusively in plants treated by methyl jasmonate and cholesterol. Chalcone isomerase catalyzes the cyclization of chalcone and 6 '-deoxychalcone into (2S)-naringenin, and (2S)-5deoxyflavanone, respectively (Gensheimer and Mushegian 2004). The activity of chalcone isomerase is substantial for the biosynthesis of phenylpropanoid compounds which participate in plant defense and flavanone precursors of floral pigments (Jez and Noel 2002).

Interestingly, 11-oxo-beta-amyrin 30-oxidase (spot 171) was up-regulated in control plants. The enzyme belongs to cytochrome CYP72A subfamily, is involved in the biosynthesis of triterpenoid saponins, and catalyzes three sequential oxidation or hydroxylation steps at C-30 of 11-oxo-beta-amyrin. In legumes like medic barrel (Medicago truncatula Gaertn.) or licorice (Glycyrrhiza glabra L.), this protein may be also responsible for the oxidation of triterpenes at positions C-22 and C-29 (Seki et al. 2011). 
In fenugreek, however, steroidal saponins (like diosgenin, tigogenin, and gitogenin) are synthesized instead of triterpene saponins (beta-amyrin, ursolic acid, and their derivates) and this protein similar to 11-oxo-beta-amyrin 30-oxidase, may be involved in steroidal saponin pathway. As biosynthesis of diosgenin, a main representative of steroidal saponins in fenugreek is still not explained, the possible participation of identified protein in biosynthesis of diosgenin should be tested and verified.

\section{Comparison of MALDI-ToF with other methods}

MALDI coupled with time-of-flight (ToF) mass analyzer is popular, simple, robust, and sensitive method to proteome analysis. Mass spectra obtained from this method are simple to interpret due to mainly singly charged ions that are generated (Aebersold and Goodlett 2001). However, in our study, a part of spots could not be identified using Mascot database. We made an effort to compare proteomic data with results obtained from fenugreek transcriptome analysis. This approach resulted in the identification of seven spots. Integration of proteomic data with transcriptome sequencing could be new pathway to enhance the efficiency of the identification process.

Besides MALDI, the LC-MS is the second important and routinely used method of proteomic analysis. It provides high sensitivity and reliability, and allows to reproducibly and to effectively match data to the predicted proteins (Lim et al. 2003). The possibility of using LC-MS could be alternative to obtained better results.

Our results indicate that treatment by methyl jasmonate and cholesterol has affected stress, defense, and biosynthesis of secondary metabolites in plants. Identified proteins were connected with alternations in photosynthesis or protein metabolism caused by oxidative stress or pathogen attack. Methyl jasmonate as an elicitor influenced up-regulation of proteins involved in stress and defense. In addition, proteins with overexpression induced by cholesterol were joined with acclimation to biotic and abiotic stresses. In both cases, chalcone isomerase was detected as one of the enzymes of phenylpropanoid pathway. This indicates overexpression of secondary metabolites pathway and structural-functional relationship between phenylpropanoid and isoprenoid pathways in plants with induced diosgenin synthesis. Biosynthesis of diosgenin originates from integration of mevalonate, non-mevalonate, and steroids pathways.

\section{Conclusions}

Proteome changes in response to methyl jasmonate and cholesterol treatment were recorded for 65 and 41 proteins, respectively. The identified proteins were most often involved in direct and indirect responses to stress caused by various treatments. Upon MeJ treatment, elevated levels of proteinase inhibitors, thioredoxin, pathogenesis-related protein, monodehydroacorbate reductase, harpin-binding proteins, lectins, and chalcone isomerase were observed. These proteins are involved in response to abiotic and biotic stresses and confirm the role of methyl jasmonate as elicitor. Proteins with altered expression induced with cholesterol were also generally related with acclimation to stress. Level of diosgenin was elevated in MeJ-treated plants. In opposite to MeJ, treatment with cholesterol not resulted in increase the level of diosgenin in fenugreek plants. Using standard PMF method, actually no new proteins for species-specific unique pathways can be identified. To identify these genes, sequencing of peptides with subsequent matching with available predicted protein databases can put more light on alternations in diosgenin metabolism in fenugreek. These findings provide new insights into the response of fenugreek proteome to a methyl jasmonate and cholesterol treatment.

Author contribution statement JC prepared plant treatment, extraction, and identification of diosgenin, interpreted scientific information, and wrote the manuscript; AB performed 2D electrophoresis and identification of protein and helped with manuscript preparation; AK performed 2D electrophoresis; MS prepared plant treatment and helped in diosgenin identification; MJ performed statistical analysis; MT coordinated experiment.

Acknowledgements Studies were supported by EU Regional Operational Program project UDA-RPPK.01.03.00-18-018/13-0 “The use of molecular and proteomic tools for identification of genes and enzymes with potential in biotechnology".

\section{Compliance with ethical standards}

Conflict of interest The authors declare that they have no conflict of interest.

Open Access This article is distributed under the terms of the Creative Commons Attribution 4.0 International License (http://crea tivecommons.org/licenses/by/4.0/), which permits unrestricted use, distribution, and reproduction in any medium, provided you give appropriate credit to the original author(s) and the source, provide a link to the Creative Commons license, and indicate if changes were made.

\section{References}

Aasim M, Khawar KM, Yalcin G, Bakhsh A (2014) Current trends in fenugreek biotechnology and approaches towards its improvement. Am J Soc Issues Hum. Fenugreek Special Issue Mar/Apr, pp 128-136

Aebersold R, Goodlett DR (2001) Mass spectrometry in proteomics. Chem Rev 101(2):269-295 
Allakhverdiev SI, Kreslavski VD, Klimov VV, Los DA, Carpentier R, Mohanty P (2008) Heat stress: an overview of molecular responses in photosynthesis. Photosynth Res 98:541-550

Ashraf M, Harris PJC (2013) Photosynthesis under stressful environments: an overview. Photosynthetica 51(2):163-190

Bocian A, Kosmala A, Rapacz M, Jurczyk B, Marczak Ł, Zwierzykowski Z (2011) Differences in leaf proteome response to cold acclimation between Lolium perenne plants with distinct levels of frost tolerance. J Plant Physiol 168:1271-1279

Caverzan A, Casassola A, Patussi Brammer SP (2016) Reactive oxygen species and antioxidant enzymes involved in plant tolerance to stress. In: Shanker A (ed) Abiotic and biotic stress in plants-recent advances and future perspectives. InTech, Rijeka, pp 463-480. doi:10.5772/61368. ISBN 978-953-51-2250-0

Chattopadhyay A, Subba P, Pandey A, Bhushan D, Kumar R, Datta A, Chakraborty S, Chakraborty N (2011) Analysis of the grasspea proteome and identification of stress-responsive proteins upon exposure to high salinity, low temperature, and abscisic acid treatment. Phytochemistry 72(10):1293-1307

Correia S, Vinhas R, Manadas B, Lourenco AS, Verissimo P, Canhoto JM (2012) Comparative proteomic analysis of auxin-induced embryogenic and nonembryogenic tissues of the solanaceous tree Cyphomandra betacea (tamarillo). J Proteome Res 11:1666-1675

De D, De B (2011) Elicitation of diosgenin production in Trigonella foenum-graecum $\mathrm{L}$. seedlings by heavy metals and signaling molecules. Acta Physiol Plant 33:1585-1590

Etienne P, Petitot AS, Houot V, Blein JP, Suty L (2000) Induction of tcI 7 , a gene encoding a $\beta$-subunit of proteasome, in tobacco plants treated with elicitins, salicylic acid or hydrogen peroxide. FEBS Lett 466:1873-3468

Faizal A, Geelen D (2013) Saponins and their role in biological processes in plants. Phytochem Rev 12:877-893

Falcone Ferreyra ML, Rius SP, Casati P (2012) Flavonoids: biosynthesis, biological functions, and biotechnological applications. Front Plant Sci 3:222-237

Farmer EE, Johnson RR, Ryan CA (1992) Regulation of expression of proteinase inhibitor genes by methyl jasmonate and jasmonic acid. Plant Physiol 98:995-1002

Fraire-Velázquez S, Rodríguez-Guerra R, Sánchez-Calderón L (2011) Abiotic and biotic stress response crosstalk in plants. In: Shanker A (ed) Abiotic stress response in plants - physiological, biochemical and genetic perspectives. InTech, Rijeka. doi:10. 5772/23217. ISBN 978-953-307-672-0

Gensheimer M, Mushegian A (2004) Chalcone isomerase family and fold: no longer unique to plants. Protein Sci 13(2):540-544

Habib H, Fazili KM (2007) Plant protease inhibitors: a defense strategy in plants. Biotechnol Mol Biol Rev 2(3):068-085

Hammerschmidt R, Nicholson RL (1999) A survey of plant defense responses to pathogens. In: Agrawal AA, Tuzun S, Bent E (eds) Inducible plant defenses against pathogens and herbivores: biochemistry, ecology, and agriculture. American Phytopathological Society Press, St. Paul, pp 55-71

Hurkman WJ, Tanaka CK (1986) Solubilization of plant membrane proteins for analysis by two-dimensional gel electrophoresis. Plant Physiol 81(3):802-806

Jez JM, Noel JP (2002) Reaction mechanism of chalcone isomerase. $\mathrm{pH}$ dependence, diffusion control, and product binding differences. J Biol Chem 277(2):1361-1369

Kang SG, Choi JH, Suh SG (2002) A leaf-specific 27 kDa protein of potato Kunitz-type proteinase inhibitor is induced in response to abscisic acid, ethylene, methyl jasmonate, and water deficit. Mol Cells 13(1):144-147

Karban R, Kuć J (1999) Induced resistance against pathogens and herbivores: an overview. In: Agrawal AA, Tuzun S, Bent E (eds) Inducible plant defenses against pathogens and herbivores: biochemistry, ecology, and agriculture. American Phytopathological Society Press, St. Paul, pp 1-16

Komatsu S, Kamal AHM, Hossain Z (2014) Wheat proteomics: proteome modulation and abiotic stress acclimation. Front Plant Sci 5:684-703

Kosová K, Vítámvás P, Prášil IT (2014) Proteomics of stress responses in wheat and barley-search for potential protein markers of stress tolerance. Front Plant Sci 5:711-725

Lambert E, Faizal A, Geelen D (2011) Modulation of triterpene saponin production: in vitro cultures, elicitation, and metabolic engineering. Appl Biochem Biotechnol 164:220-237

Li XJ, Yang MF, Chen H, Qu LQ, Chen F, Shen SH (2010) Abscisic acid pretreatment enhances salt tolerance of rice seedlings: proteomic evidence. Biochim Biophys Acta 1804:929-940

Li W, Zhao F, Fang W, Xie D, Hou J, Yang X, Zhao Y, Tang Z, Nie L, Lv S (2015) Identification of early salt stress responsive proteins in seedling roots of upland cotton (Gossypium hirsutum L.) employing iTRAQ-based proteomic technique. Front Plant Sci 6:732-746

Lim H, Eng Yates JR, Tollaksen SL, Giometti CS, Holden JF, Adams MW, Reich CI, Olsen GJ, Hays LG (2003) Identification of 2Dgel proteins: a comparison of MALDI/TOF peptide mass mapping to mu LC-ESI tandem mass spectrometry. J Am Soc Mass Spectrom 14(9):957-970

Mehrafarin A, Rezazadeh Sh, Naghdi Badi H, Noormohammadi Gh, Zand E, Qaderi A (2011) A review on biology, cultivation and biotechnology of fenugreek (Trigonella foenum-graecum L.) as a valuable medicinal plant and multipurpose. J Med Plants 10:6-24

Murashige T, Skoog F (1962) A revised medium for rapid growth and bioassays with tobacco tissue cultures. Physiol Plant 15:473-497

Nam MH, Huh SM, Kim KM, Park WJ, Seo JB, Cho K, Kim DY, Kim BG, Yoon IS (2012) Comparative proteomic analysis of early salt stress-responsive proteins in roots of SnRK2 transgenic rice. Proteome Sci 10:25-44

Noctor G, Foyer CH (1998) Ascorbate and glutathione: keeping active oxygen under control. Annu Rev Plant Physiol Plant Mol Biol 49:249-279

Nordhoff E, Egelhofer V, Giavalisco P, Eickhoff H, Horn M, Gobom $\mathrm{J}$ et al (2001) Large-gel two-dimensional electrophoresis-matrix assisted laser desorption/ionization-time of flight-mass spectrometry: an analytical challenge for studying complex protein mixtures. Electrophoresis 22:2844-2855

Nouri MZ, Moumeni A, Komatsu S (2015) Abiotic stresses: insight into gene regulation and protein expression in photosynthetic pathways of plants. Int J Mol Sci 16:20392-20416. doi:10.3390/ ijms 160920392

Patel K, Gadewar M, Tahilyani V, Patel DK (2012) A review on pharmacological and analytical aspects of diosgenin: a concise report. Nat Prod Bioprospect 2:46-52

Raines CA, Paul MJ (2006) Products of leaf primary carbon metabolism modulate the developmental programme determining plant morphology. J Exp Bot 57:1857-1862

Raines C, Lloyd J, Dyer T (1999) New insights into the structure and function of sedoheptulose-1,7-bisphosphatase an important but neglected calvin cycle enzyme. J Exp Bot 50:1-8

Raju J, Rao CV (2012) Diosgenin, a steroid saponin constituent of yams and fenugreek: emerging evidence for applications in medicine. In: Rasooli I (ed) Bioactive compounds in phytomedicine. InTech, Rijeka, pp 125-142. doi:10.5772/26700

Rathi D, Gayen D, Gayali S, Chakraborty S, Chakraborty N (2016) Legume proteomics: progress, prospects, and challenges. Proteomics 16:310-327

Rejeb IB, Pastor V, Mauch-Mani B (2014) Plant responses to simultaneous biotic and abiotic stress: molecular mechanisms. Plants 3:458-475 
Rey P, Cuiné Eymery F, Garin J, Court M, Jacquot JP, Rouhier N, Broin M (2005) Analysis of the proteins targeted by CDSP32, a plastidic thioredoxin participating in oxidative stress responses. Plant J 41(1):31-42

Ryan CA (1990) Proteinase inhibitors in plants: genes for improving defenses against insects and pathogens. Annu Rev Phytopathol 28:425-449

Savikin-Fodulovic K, Grubisic D, Culafic L, Menkovic N, Ristic M (1998) Diosgenin and phytosterols content in five callus lines of Dioscorea balcanica. Plant Sci 135:63-67

Seki H, Sawai S, Ohyama K, Mizutani M, Muranaka T et al (2011) Triterpene functional genomics in licorice for identification of CYP72A154 involved in the biosynthesis of glycyrrhizin. Plant Cell 23:4112-4123

Sharma P, Jha AB, Dubey RS, Pessarakli M (2012) Reactive oxygen species, oxidative damage, and antioxidative defense mechanism in plants under stressful conditions. J Bot 2012:1-16

Snehlata HS, Payal DR (2012) Fenugreek (Trigonella foenumgraecum L.): an overview. Int $\mathbf{J}$ Curr Pharm Rev Res 2(4):169-187

Song C, Zeng F, Feibo W, Ma W, Zhang G (2010) Proteomic analysis of nitrogen stress-responsive proteins in two rice cultivars differing in $\mathrm{N}$ utilization efficiency. J Integr Omics 1(1):78-87

StatSoft, Inc. (2010) STATISTICA (data analysis software system), version 9.1. http://www.statsoft.com
Szakiel A, Pączkowski C, Henry M (2011) Influence of environmental biotic factors on the content of saponins in plants. Phytochem Rev 10:493-502

Vítámvás P, Urban MO, Škodáček Z, Kosová K, Pitelková I, Vítámvás J, Renaut J, Prášil IT (2015) Quantitative analysis of proteome extracted from barley crowns grown under different drought conditions. Front Plant Sci 6:479-497

Wang X, Tang C, Deng L, Cai G, Liu X, Liu B, Kang et al (2010) Characterization of a pathogenesis-related thaumatin-like protein gene TaPR5 from wheat induced by stripe rust fungus. Physiol Plant 139(1):27-38

Wang T, Chen X, Zhu F, Li H, Li L, Yang Q, Chi X, Yu S, Liang X (2013) Characterization of peanut germin-like proteins, AhGLPs in plant development and defense. PLoS One 8(4):e61722. doi:10.1371/journal.pone.0061722

Weiss W, Görg A (2007) Two-dimensional electrophoresis for plant proteomics. Methods Mol Biol 355:121-143

Willekens H, Chamnongpol S, Davey M, Schraudner M, Van Camp W et al (1997) Catalase is a sink for $\mathrm{H}_{2} \mathrm{O}_{2}$ and is indispensable for stress defence in C-3 plants. EMBO J 16(16):4806-4816

Zhang L, Xiao S, Li W, Feng W, Li J, Wu Z, Gao X, Liu F, Shao M (2011) Overexpression of a harpin-encoding gene hrf1 in rice enhances drought tolerance. J Exp Bot 62(12):4229-4238 